\title{
ASEE Student Chapter Longevity and Programming
}

\section{Ms. Rebecca Marie Reck, University of Illinois, Urbana-Champaign}

Rebecca M. Reck is currently pursuing a Ph.D. in systems engineering at the University of Illinois at Urbana-Champaign. She completed her master's degree in electrical engineering at Iowa State University during her eight years at Rockwell Collins and her bachelor's degree in electrical engineering with a mathematics minor, from Rose-Hulman Institute of Technology in 2005. Her research interests include controls, signal processing, and engineering education. Specific areas of controls and signal processing research include the design and modeling of intelligent controls, Kalman filters, and automation. Engineering education research includes curriculum and laboratory development for these concepts.

\section{Mrs. Anastasia Marie Rynearson, Purdue University, West Lafayette}

Anastasia Rynearson is a Purdue Doctoral Fellow pursuing a degree in Engineering Education at Purdue University. She received a B.S. and M.Eng. in Mechanical Engineering at the Rochester Institute of Technology. Her teaching experience includes outreach activities at various age levels as well as a position as Assistant Professor in the Mechanical Engineering Department at Kanazawa Technical College. Her current research interests focus on early P-12 engineering education and identity development.

\section{Mr. Matthew William Priddy, Georgia Institute of Technology}

Matthew W. Priddy is currently pursuing a Ph.D. in mechanical engineering at the Georgia Institute of Technology. He completed his bachelor's and master's degrees in civil engineering at Mississippi State University in 2008 and 2010, respectively. His research interests include computational solid mechanics and lightweight metals, specifically microstructure-sensitive materials modeling and design. He also has an interest in engineering education research, particularly in future faculty development. 


\title{
ASEE Student Chapter Longevity and Programming
}

\begin{abstract}
Since 1993, approximately 32 ASEE Student Chapters have been created across the U.S, but only 16 of those Chapters are currently active. From limited information, it seems even fewer active Chapters are making a significant contribution to the student population at their respective schools. This study determined the level of Chapter-organized programming and member involvement via a voluntary web survey given specifically to all ASEE Student Chapters and the more general national student member and recent graduate population. The resulting data was aggregated and analyzed to identify common characteristics among Student Chapter offerings. This paper organized the data into common themes of programming that include teaching assistant training, faculty job preparation, and sharing engineering education research. The paper discusses Student Chapter offerings and proposes ideas for future programming and longevity of ASEE Student Chapters.
\end{abstract}

\section{Introduction}

The first American Society for Engineering Education (ASEE) Student Chapter was founded at Purdue University in $1993^{1}$ and since that time, over 30 additional Chapters have been formed in institutions across the United States with sixteen Chapters currently holding active status. ${ }^{2}$

Student Chapters have been important ways for engineering graduate students interested in education to connect and grow their knowledge base and professional network. The constant advance of technology and the emergence of engineering education programs across the U.S. have changed the playing field for graduate students seeking to discuss engineering education with their peers. Every few years, there is an analysis of the needs of graduate students involved in engineering education. ${ }^{3-5}$ This study is a look at the current landscape of ASEE's Student Chapters.

Students have a long history as members of ASEE. Jim Jones, a Mechanical Engineering professor, was the adviser for the creation of the first Student Chapter at Purdue University in 1993. ${ }^{6}$ Student Chapters expanded to other institutions with strong student membership in ASEE. During the 2000s, student membership increased from 549 students in June 2005 to 728 students in June 2010. During this time, there was a recognized need for student representation in ASEE, so the Student Constituent Committee was formed at the 2007 Annual Conference \& Exposition. This committee became the Student Division in 2011 ${ }^{1}$; currently, there are 798 student members of ASEE.

Students at 32 institutions have identified needs that they believed could be met through forming an ASEE Student Chapter. Unfortunately, half of those Student Chapters are now dormant for a variety of reasons: students may have had unmet needs, found that the ASEE Chapter had different priorities, or simply did not have the core group of students needed to continue. Prior articles have questioned the appropriateness of the Student Chapter Mission for all Student Chapters. ${ }^{8}$ Surveys of student needs have considered the needs of ASEE students as a whole, providing guidance for the Student Constituent Committee, later the Student Division, rather than the individual Student Chapters. While prior reports are not geared toward campus-based Student Chapters, their findings can have an influence on Student Chapters in addition to the overall Student Division. Carberry, Bumblauskas, Coso, and Torres-Ayala found that the 
majority of students who took the survey were interested in engineering education research, academic jobs, or engineering education in general. ${ }^{5}$ Torres-Ayala, Bumblauskas, and Verleger had the same findings and expanded their research to include perceived benefits of ASEE membership, including networking, publications (such as access to JEE), news on engineering education, and access to engineering education research as the most commonly mentioned benefits. ${ }^{9}$ Both surveys found that the most common participation in ASEE for survey participants was the National Conference, followed by campus-based Student Chapter activities. This information can help focus Student Chapter programming, but does not explicitly discuss needs of students that can be met by Student Chapters.

Student Chapters are active at sixteen institutions in the United States. These institutions range from community colleges to undergraduate serving institutions and research-focused universities, both with and without engineering education degree programs. ${ }^{1}$ With such a wide range of institutions being served with Student Chapters, it can be difficult to ensure that all needs are met and all Chapters have the same goals.

According to the ASEE Student Chapter Mission, ${ }^{1}$ the general mission of Student Chapters is:

I. To develop relationships with local schools (K-12) and aid them in fostering student interest in future careers and study in engineering and engineering technology

II. To encourage engineering undergraduate students to continue their studies on the graduate level

III. To increase the interest of engineering graduate students in careers in engineering education

IV. To assist and encourage minorities and women to study and seek careers in the fields of engineering and engineering technology

V. To promote scholarships, fellowships, and post-doctoral opportunities for ASEE student members

VI. To provide opportunities for students to gain insight into academic careers and teaching practices

As of this writing, no study has been done to broadly understand what ASEE Student Chapters offer their members or what the members of ASEE Student Chapters need from their local Chapters. Most prior studies have taken a look at the broader programming provided by the Student Constituent Committee, now the Student Division, rather than the programming provided by local Student Chapters. ${ }^{5} 9$ Some have been a case study of specific Student Chapters. ${ }^{3,10,11}$ Others have offered suggestions for how Student Chapters can meet the needs of their members, or guides for how to create or revive a Student Chapter. ${ }^{12,13}$ This study seeks to understand what Student Chapters currently do for their members on a local level, including programming provided and other support given. This study also considers what needs students involved in ASEE have that their institutions may be meeting and what needs are within the realm of engineering education that are not being met. This paper will provide an overview of the current state of ASEE Student Chapter attributes and areas that need attention. 


\section{Methods}

A survey research design was used to identify the needs of local Student Chapter members and to determine if and how those needs are being met.

\section{Participant Demographics}

The survey had 90 participants, with 72 completing the entire survey (80\% completion rate) and a range of item response rates between $23 \%$ and $98 \%$. Participant demographics included $42 \%$ males $(n=29)$ and $58 \%$ females $(n=40), 88 \%$ reported as domestic $(n=49)$ while $13 \%$ reported international student status $(n=7), 78 \%$ held national ASEE memberships $(n=69)$, 93\% had Student Chapters available at their institution $(\mathrm{n}=78)$, and $67 \%$ attended Student Chapter meetings $(n=60)$. Half of respondents $(50 \%)$ respondents are currently in leadership positions in their Student Chapter $(n=35)$, while $77 \%$ had been officers in past years $(n=27)$. The majority of respondents were graduate students $(68 \%, n=48)$ as seen in Figure 1. Based on these demographics, the respondents are likely highly involved in their ASEE Chapters; this selfselection is a limitation of the study.

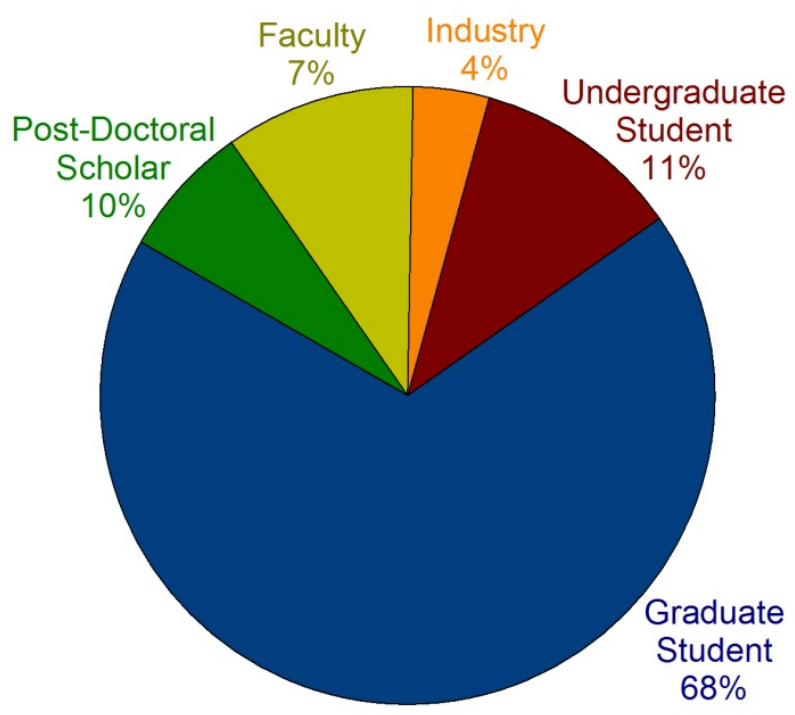

Figure 1. Primary classification of survey respondents $(n=71)$.

\section{Data Collection}

This voluntary study used an electronic survey through Qualtrics software ${ }^{14}$ to gather data from past and present ASEE Student Chapter members. Responses were also recorded from participants who were not involved in Student Chapters (e.g. students that attend a university that does not have an ASEE Student Chapter); these participants were able to speak about what their university offers and what they would want from a Student Chapter. Items included in the survey include demographics of the respondent (e.g. gender, university, educational level), current programming offerings from Student Chapter, future programming of interest for the respondent, and some specific questions for faculty/staff/post-docs and current Student Chapter leaders. The survey was distributed electronically through social media (e.g. Facebook and Twitter) as well as through ASEE newsletters and the Student Division and Student Chapter e-mail lists. 
The survey was created and analyzed by current ASEE Student Chapter Presidents, using their experience with their Student Chapters to craft the survey as well as prior surveys of ASEE Student Chapters. The number of questions varied due to responses of participants, up to a maximum of 43 questions. These questions were mainly multiple choice with some fill-in-theblank options. All questions were voluntary, meaning the respondents were not required to complete any of the questions. The full survey is included in the Appendix.

All survey responses from Qualtrics ${ }^{14}$ were imported into Microsoft Excel for analysis. Results are presented as pie charts where all respondents were allowed to choose one option and bar charts where respondents could choose multiple options.

\section{Results}

Overall, survey participants are satisfied $(62 \%, n=46)$ or very satisfied $(24 \%, n=18)$ with their experiences with ASEE Student Chapters, as shown in Figure 2. A total of $14 \%$ of respondents reported either dissatisfied $(11 \%, n=8)$ or very dissatisfied $(3 \%, n=2)$ with their ASEE Student Chapters. Results are displayed by components of the Student Chapter Mission.

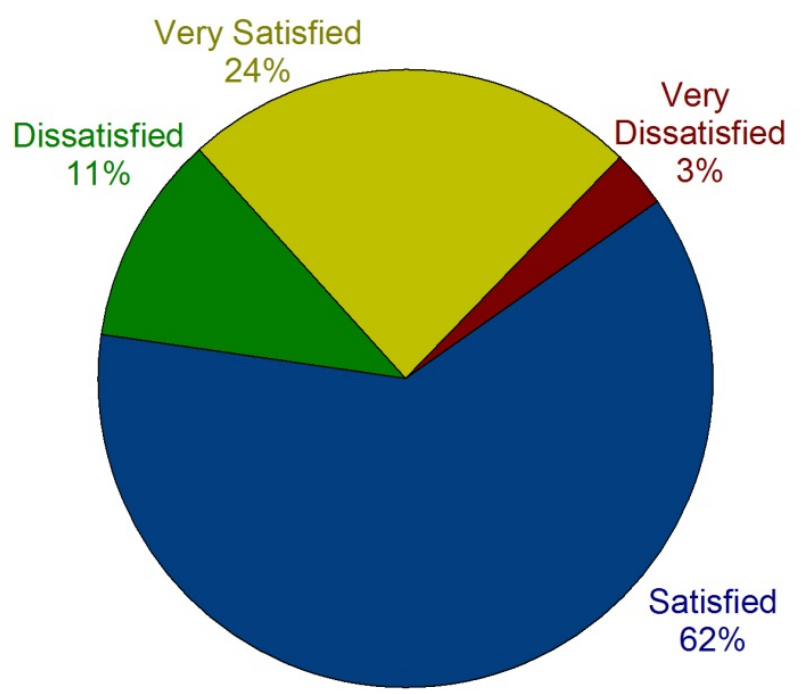

Figure 2. Satisfaction level with ASEE Student Chapters $(\mathrm{n}=74)$.

The remaining results are presented in a manner such that they address each specific mission listed in the Introduction section.

Student Chapters offer various types of programming that can increase the interest of engineering graduate students in engineering education careers (Mission III). Types of programming were categorized into four general areas: (1) teaching preparation, (2) research, (3) academic assistance, and (4) job search. Within the survey, respondents were asked (a) which types of programming were currently being offered and (b) which types of programming would they like to see in the future. The results are shown in Figure 3. The majority of respondents indicated that their Student Chapter offers teaching preparation $(63 \%, \mathrm{n}=42)$ and research $(72 \%$, $\mathrm{n}=48)$ programming, while academic assistance $(40 \%, \mathrm{n}=27)$ and job search $(37 \%, \mathrm{n}=25)$ 
programming was less likely to be offered. The majority of respondents also indicated interest in programming being offered from all four general areas.

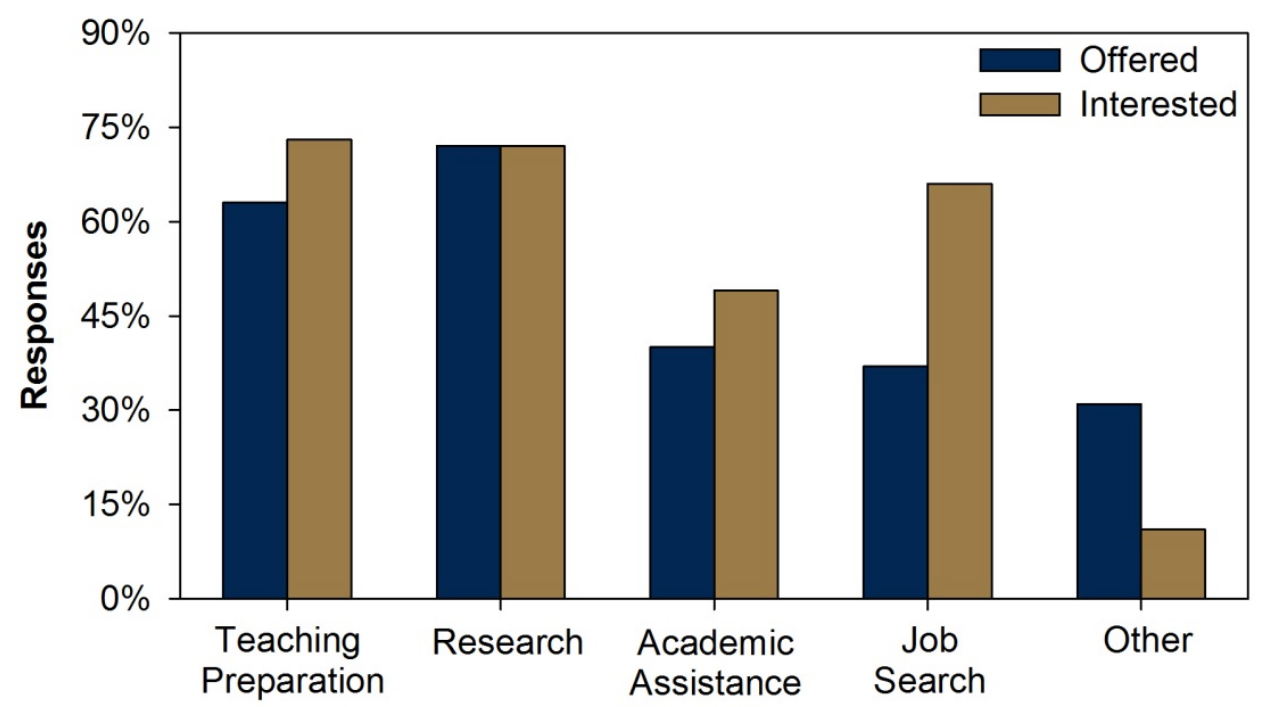

Figure 3. Types of overall programming offered by ASEE Student Chapters $(n=67)$ compared with interest $(\mathrm{n}=71)$.

The majority of respondents $(88 \%, \mathrm{n}=52)$ stated that their institutions offer teaching assistant (TA) training and/or teaching certificates for graduate students, which address Mission VI. Additionally, many Student Chapters also offer programming focusing on academic careers and teaching practices, as shown in Figure 4.

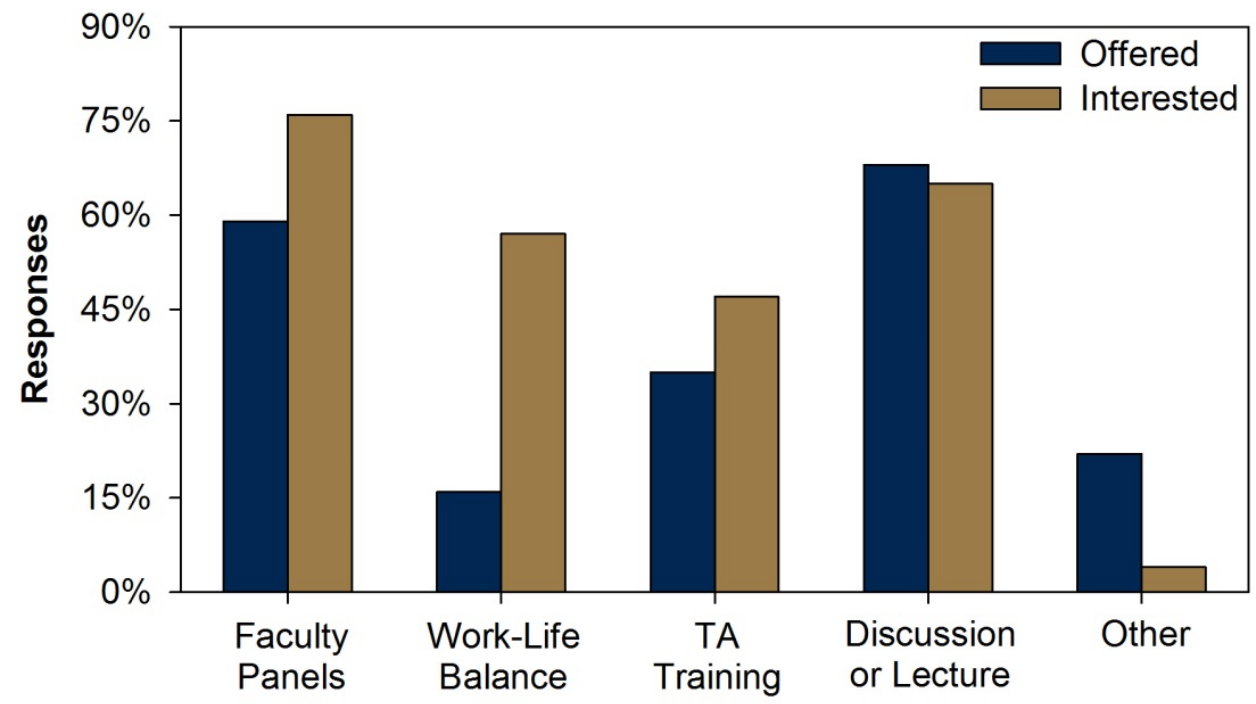

Figure 4. Types of teaching-focused programming offered by ASEE Student Chapters $(\mathrm{n}=37)$ compared with interest $(n=49)$. 
In particular, the majority of respondents note that their Chapters are offering faculty panels and discussions/lectures on teaching-related topics, while the respondents are interested in seeing a higher level of offerings involving work-life balance and TA training.

Research is another area of programming that is commonly offered by ASEE Student Chapters, Figure 5 shows the various programming topics in this area. Figure 5 indicates that respondents would like to see more programming offered for all research-related categories, which isn't all that surprising. Since engineering education research is still a niche research field on most engineering campuses, we believe students are unsure of how to navigate the professional landscape when it comes to research and conference preparation.

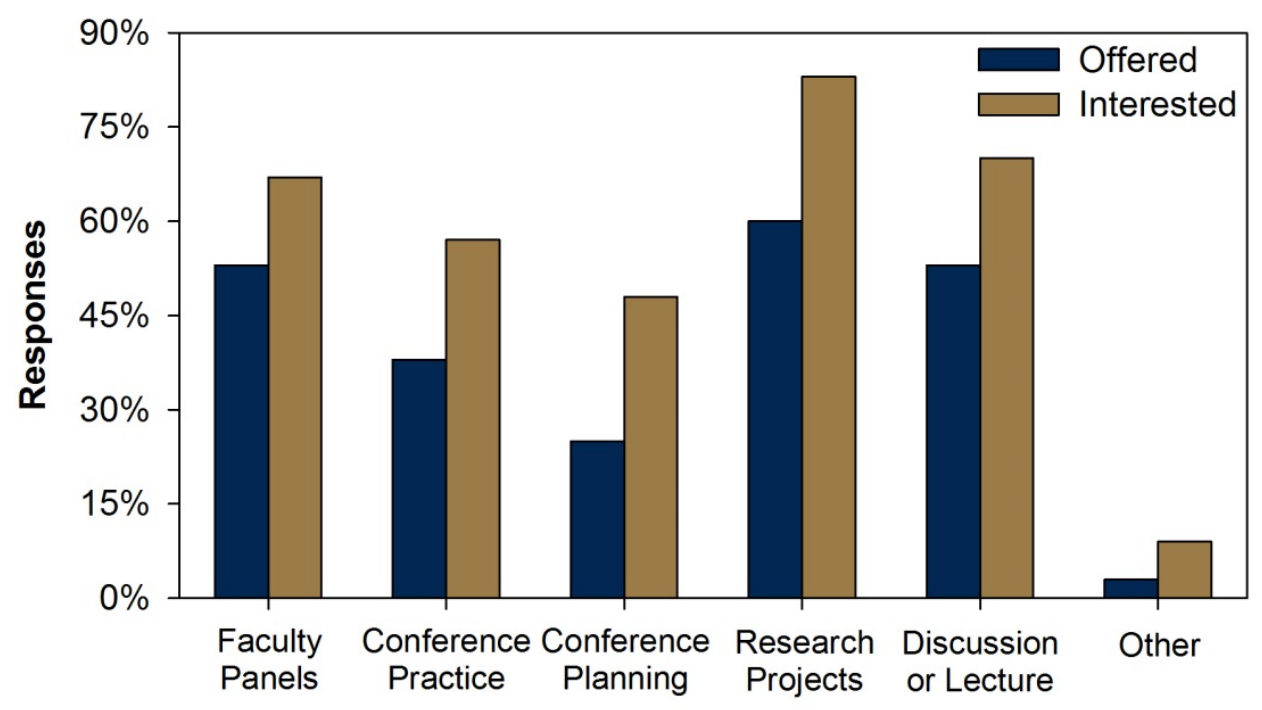

Figure 5. Types of research-related programming offered by ASEE Student Chapters $(n=40)$ compared with interest $(n=46)$.

The survey did not address each mission statement explicitly, but some of the responses did address various mission statements. For example, two respondents stated their Chapter offered outreach programming (Mission I). Two respondents felt that their Chapter should offer outreach programming for K-12 students. Also, two respondents noted community outreach as their "favorite ASEE program or event". Additionally, four undergraduates responded to the survey and one respondent noted that there are typically 20 - 30 undergraduate members of their Student Chapter, which is related to Mission II. This survey does not provide enough data to describe Student Chapter offerings in this area.

One respondent noted that their "favorite ASEE program or event" was a "talk on research related to underrepresentation in engineering" and another respondent noted partnering with minority-serving organizations like Society of Women Engineers for events, which addresses Mission IV. However, this aspect of the Mission was not adequately addressed in the survey. The majority of respondents were female, however that may not be reflective of Student Chapters assisting underrepresented groups to seek careers in engineering and engineering technology. Lastly, one response discussed the need for their ASEE Student Chapter to promote internship and fellowship opportunities and one participant noted that their Student Chapter offered grant writing workshops (Mission V). 


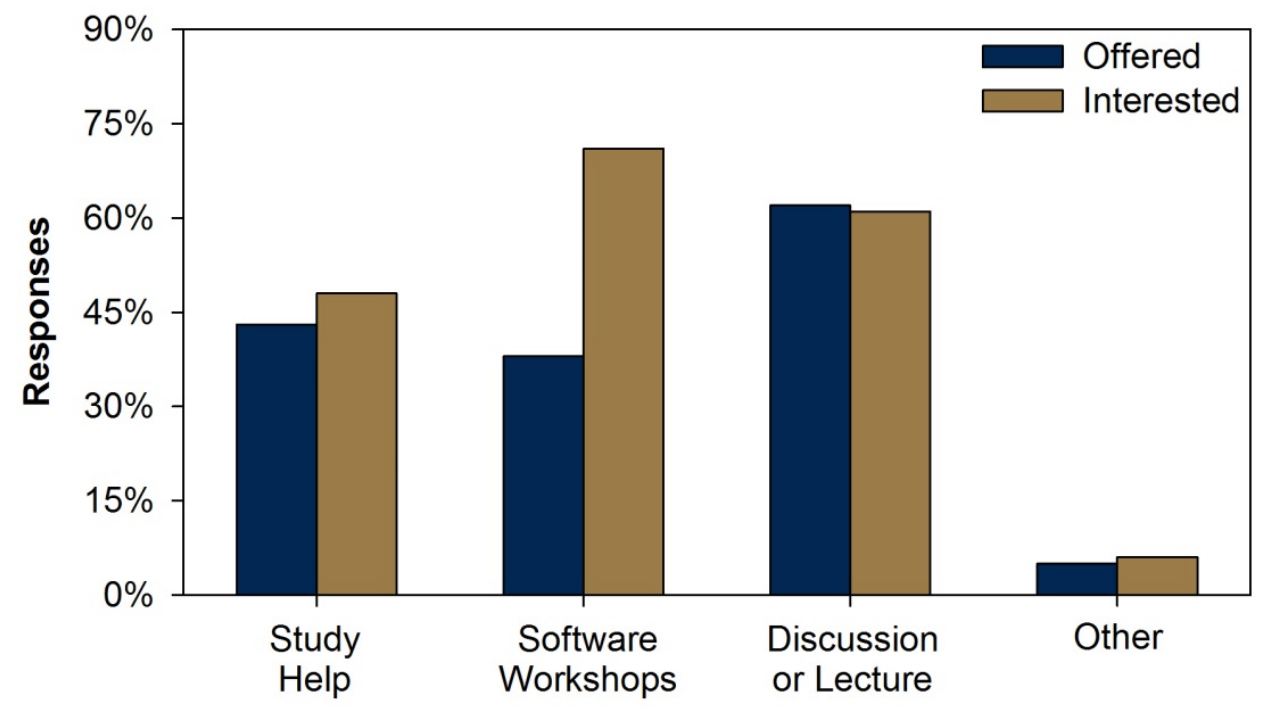

Figure 6. Types of academic programming offered by ASEE Student Chapters $(\mathrm{n}=21)$ compared with interest $(n=31)$.

In addition to Mission-focused programming, other notable results have been found through the survey. Social and networking events were noted as common programming. Chapters also incorporate academically-oriented programming (Figure 6) and assist with various aspects of academic job search and preparation (Figure 7).

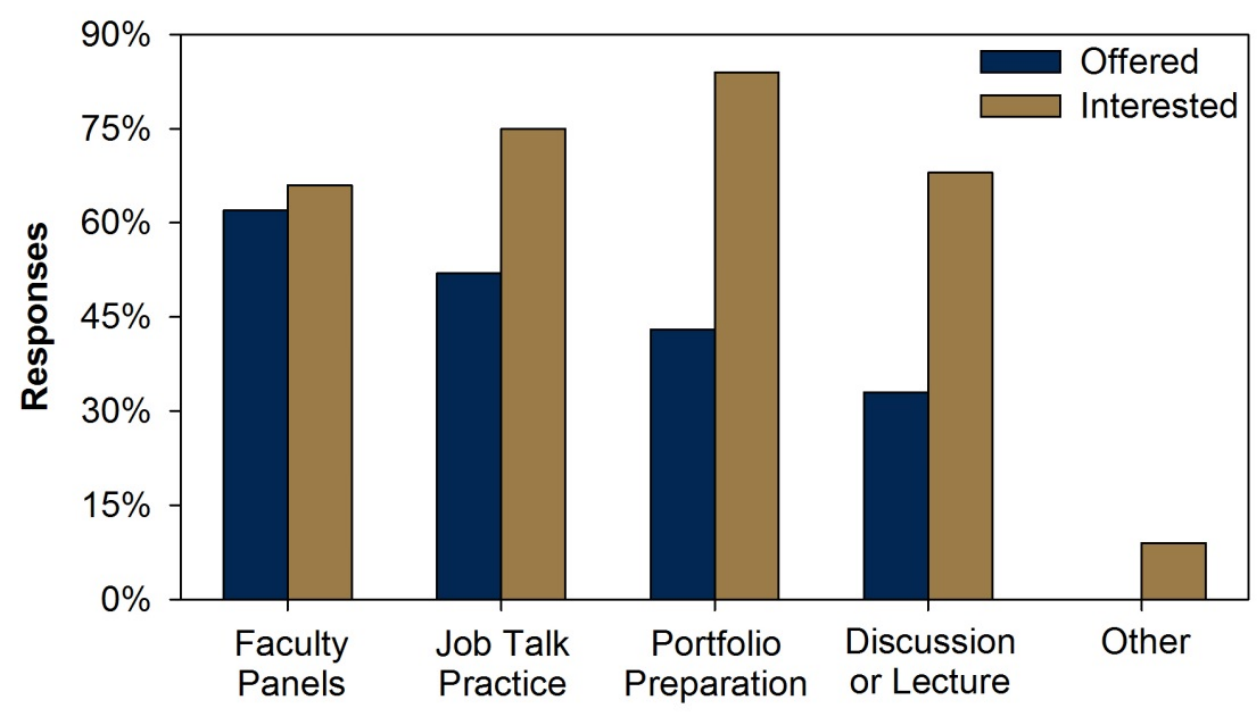

Figure 7. Types of job search programming offered by ASEE Student Chapters $(\mathrm{n}=21)$ compared with interest $(n=44)$. 


\section{Discussion}

Based on the survey, few Student Chapters meet the first point in the Mission, which involved K12 outreach. Some students felt their Chapter should offer outreach programming. Additionally, few Chapters seem to focus on increasing interest in engineering or encouraging engineering undergraduates to attend graduate school. The majority of programming offered by ASEE Student Chapters tends to focus on job preparation and engineering education research, areas that are not explicitly in the Mission. Active Student Chapters are meeting the needs of their members, but this may not be reflected in the overall Student Division governing documents.

While Student Chapters have high satisfaction ratings, there is always room for improvement. The final section of results details the interests of student members in Chapter-provided programming. Some respondents are interested in greater outreach or social programming, but for the most part, participants want their ASEE Student Chapters to be focused on teaching and research. Participants are most interested in faculty panels for teaching programming, presumably learning from the experts, and are interested in research projects as research-focused programming.

Student Chapters are valuable for a variety of reasons. First and foremost, they provide individuals with an opportunity to interact with students that have an interest in engineering education. The common interest in engineering education is interdisciplinary, meaning individuals may interact with people from other academic majors and backgrounds. This can be important in helping focus on the larger picture, not issues that are specific to any one field. ASEE Student Chapters also hold an interesting position because the combined nature of research and teaching complement each other in this instance. In other student organizations, research findings don't tend to affect the classroom culture. With engineering education, the research findings can have a direct effect on the classroom.

Recommendations for programming depend on the institutional population. The data clearly indicate the topics of programming that are desired by current members. There is often overlap between ASEE and other student organizations or units on campus, such as a teaching and learning center. There are two ways to approach this overlap. The first is to make the ASEE programming unique. On large campuses, some Chapters have found success in providing STEM-specific content as a supplement to the campus-level content for all majors. The second approach is to partner with other organization(s). This approach has extra benefits; it exposes ASEE and its mission to the members of other organizations and it can provide extra assistance for planning and execution. For research-specific programming, some campuses have found success with ASEE-hosted STEM education poster sessions. While almost $90 \%$ of the respondents reported having some campus-level teaching programming, at least 65\% reported that they are interested in ASEE providing programming in this area. STEM-focused or more indepth discussions may be a way for ASEE Student Chapters to meet this need. These unique approaches may also be a way to meet the job preparation need found through the survey. There seems to be a significant interest in a venue for job talk practice and teaching portfolio preparation, needs that may not be met in campus-level programming. Outreach was not specifically addressed in the survey, however from the authors' experience STEM outreach to the community is sufficiently covered by other organizations on campus. For some Chapters, it may be difficult to create a unique outreach experience, so again contributing to other events is a way to meet this need. 
Acquiring and retaining new members has been the biggest challenge for most Student Chapters. Many campuses do not have a strong engineering education community, so many of our members have been individuals that are interested in a career in academia. The key to obtaining new members is to identify your target audience and programming of interest. This can be through TA training or e-mail lists, engineering graduate student organizations, and departments or faculty that engage with the engineering education community. Member retention can be increased through providing programming that both interesting and useful. Leadership of ASEE Student Chapters should be aware of programming available on their campus and may consider surveying their members (and prospective members) to better understand what offerings would be desirable at their campus. For survey ideas, the survey used for this study is found in the Appendix.

\section{Conclusions}

The Student Chapter Mission as presented by the Student Division of ASEE may not be appropriate for all Student Chapters. Those from community colleges or undergraduate-serving institutions are not likely to have a graduate student population, making the third bullet, "To increase the interest of engineering graduate students in careers in engineering education”, inappropriate for these Chapters. Other Chapters may have difficulty making and keeping ties with local K-12 schools or engaging in outreach; some may find no need to do so at their institution due to ongoing outreach efforts. Still other organizations may have difficulty finding a constituency that needs support or assistance in engineering education promotion, especially in those institutions with strong instructional support or engineering education degree programs.

Student Chapters are extremely diverse and have diverse needs. There are also common needs that reach across the varying demographics of ASEE Student Chapters. Teaching, research, and job preparation are common needs filled by some Chapters and requested by others. Some institutions provide teaching training and certification as others look to their ASEE Chapters for instruction. While are common across the participants of the survey, these needs may vary by school.

This paper presents an overview of the current needs and interests of ASEE Student Chapters. It is recommended that this information is disseminated to current and future Student Chapter Presidents and that a needs analysis study is undertaken every few years, as it has been, to ensure Student Chapters and ASEE's organizational leaders in the Student Division are aware of the wants and needs of their constituents.

\section{Acknowledgements}

The authors would like to thank Dr. Michael Loui for his assistance with IRB approval, and the ASEE Student Division and ASEE Student Chapter Presidents for distributing the survey. MWP would like to thank Dr. Alexandra Coso (Postdoctoral Scholar at Georgia Tech) for her input specific to the survey and sponsorship of the IRB protocol at GT. 
References

[1] "Student chapters", ASEE Student Division: A blog for the students in the American Society for Engineering Education: ASEE Student Division.

[2] Carberry, A., "Engineering education communities and societies": engineeringeducationlist, 2011.

[3] Berger, E. J., Diefes, H. A., Hamaker, K. H., Jones, J. D., McComb, S. A., Mulkay, E. L., and Oakes, W. C., "Asee student chapters: Perspectives on and preparation for higher education", Journal of Engineering Education Vol. 87, No. 3, 1998, pp. 231-234.

[4] Barr, R. E., "Asee student chapters: Addressing the needs of future engineering educators", 2001 GulfSouthwest Annual Conference, College Station, TX: American Society for Engineering Education, 2001.

[5] Carberry, A. R., Bumblauskas, D. P., Coso, A. E., and Torres-Ayala, A. T., "Student satisfaction with asee activities and its impact on asee student membership", 2011 Annual Conerence \& Exposition, Vancouver, B.C., Canada: American Society for Engineering Education, 2011.

[6] Mullenax, C., "Student involvement in asee-past, present, and future", 2005 American Society for Engineering Education Annual Conference \& Exposition, Portland, OR: American Society for Engineering Education, 2005.

[7] "Electronic membership directory", ASEE: American Society for Engineering Education: ASEE: American Society for Engineering Education, 2015.

[8] Visco, D. P., and Cartwright, A. N., "A new model for asee student chapters", Journal of Engineering Education Vol. 90, No. 4, 2001, pp. 641-643.

[9] Torres-Ayala, A., Bumblauskas, D., and Verleger, M., "Asee student members' needs analysis: Implications for the asee student constituent committee", Midwest Section Conference of the American Society for Engineering Education, Lawrence, KS: American Society for Engineering Education, 2010.

[10] Norton, J., and Rogers, R., "Victim of success: The changing mission of an asee student chapter", 2006 Annual Conference \& Exposition, Chicago, IL: American Society for Engineering Education, 2006.

[11] Oliver, K. M., Hoskinson, A. R., and Azarin, S. M., "Student chapters by analogy: Lessons from comparing asee student organizations with those of other professional societies", 2008 ASEE North Midwest Sectional Conference, Platteville, WI: American Society for Engineering Education, 2008.

[12] Van Ruitenbeek, E., "Successful publicity strategies for a new asee student chapter", 2010 ASEE Annual Conference \& Exposition, Louisville, KY: American Society for Engineering Education, 2010.

[13] Rogers, R., Lachawiec, A., and Ringenberg, J., "To sink or swim: Effective strategies for maintaining and nurturing an asee student chapter.", 2008 ASEE Annual Conference \& Exposition, Pittsburgh, PA:

American Society for Engineering Education, 2008.

[14] Qualtrics, "Qualtrics", Provo, Utah: Qualtrics, 2013. 


\section{Appendix: Survey Questions}

\section{ASEE Student Chapter Information Section}

(This section was presented to all respondents)

Are you a member of ASEE national organization?

- Yes

- No

Does your campus have an ASEE Student Chapter?

- Yes

- No

- Don't know

Do you attend campus ASEE meetings?

- Yes

- No

How satisfied with are you with your ASEE Student Chapter?

- Very Dissatisfied

- Dissatisfied

- Satisfied

- Very Satisfied

- Not applicable

What forms of programming does your ASEE Student Chapter offer? Check all that apply:

$\square \quad$ Teaching Preparation

$\square$ Research

$\square$ Academic Assistance

Job Search

$\square \quad$ Other

$\square \quad$ Not applicable
What types of teaching-related programming? Check all that apply:

$\square \quad$ Faculty panels

$\square \quad$ Work-life balance

$\square \quad$ TA Training

$\square$ Discussion or Lecture

$\square \quad$ Other

What types of research-related programming? Check all that apply:

$\square \quad$ Faculty panels

$\square \quad$ Conference Practice

$\square \quad$ Conference Planning

$\square \quad$ Research projects

$\square \quad$ Discussion or lecture

$\square$ Other

What types of academic assistance programming? Check all that apply:

$\square \quad$ Study help

$\square$ Software workshops

$\square$ Discussion or lecture

$\square \quad$ Other

What types of job search programming? Check all that apply:

$\square \quad$ Faculty panels

$\square \quad$ Job talk practice

$\square \quad$ Portfolio preparation

$\square \quad$ Discussion or Lecture

$\square \quad$ Other

Please describe your favorite ASEE program or event:

(open response question) 
What forms of programming would you be interested in? Check all that apply:

$\square \quad$ Teaching preparation

$\square \quad$ Research

$\square \quad$ Academic Assistance

$\square \quad$ Job Search

$\square$ Other

What types of teaching-related programming? Check all that apply:

$\square \quad$ Faculty panels

$\square \quad$ Work-life balance

$\square \quad$ TA Training

$\square$ Discussion or Lecture

$\square \quad$ Other

What types of research-related

programming? Check all that apply:

$\square$ Faculty panels

$\checkmark$ Conference Practice

$\square \quad$ Conference Planning

Research projects

$\square$ Discussion or lecture

$\square$ Other

What types of academic assistance programming? Check all that apply:

$\square \quad$ Study help

- Software workshops

$\square$ Discussion or lecture

$\square$ Other

What types of job search programming?

Check all that apply:

- Faculty panels

$\square$ Job talk practice

$\square \quad$ Portfolio preparation

$\square$ Discussion or Lecture

$\square$ Other

What would you like your ASEE Student Chapter to do for you?

(open response question)
What kind of advertising works best for you? Check all that apply:

$\begin{array}{ll}\square & \text { E-mail } \\ \square & \text { Facebook } \\ \square & \text { Flyers } \\ \square & \text { Word of mouth } \\ \square & \text { Other social media } \\ \square & \text { Other }\end{array}$

Are you currently in a leadership position or interested in a leadership position in your ASEE Student Chapter?

- Yes

- No

Does your school offer any of the following? Check all that apply

$\square \quad$ TA Training

$\square \quad$ Teaching Certificate

How much TA training is available?

- Less than $1 / 2$ day required

- Between $1 / 2$ and 1 day required

- More than 1 day required

- Less than $1 / 2$ day optional

- Between $1 / 2$ and 1 day optional

- More than 1 day optional

What are the requirements for the Teaching Certificate(s)?

(open response question)

Does ASEE programming count toward teaching certificate requirements?

- Yes

- No

- Sometimes

Does ASEE service count toward teaching certificate requirements?

- Yes

- No

- Sometimes 


\section{Demographic Section}

(This section was presented to all respondents)

What is your gender?

- Male

- Female

- Other

What degree(s) do you currently hold?

Check all that apply:

$\square \quad$ Associate's

$\square$ Bachelor's

$\square$ Master's

$\square$ Ph.D.

$\square$ Other

What degree(s) are you currently pursuing?

Check all that apply:

$\square \quad$ Associate's

$\square$ Bachelor's

$\square$ Master's

$\square$ Ph.D.

$\square$ Other

$\square$ None

What is your primary classification?

- Undergraduate student

- Graduate student

- Post-Doc

- Faculty

- Staff

- Industry

- Other
If applicable, are you considered a domestic or international student?

- Domestic

- International

What institution do your answers to all of the previous questions apply to? Check one:

- Austin Community College

- CUNY

- Georgia Institute of Technology

- IUPUI

- Michigan Technological University

- Ohio Northern

- Ohio State University

- Purdue University

- Stanford University

- Tufts University

- Tuskegee University

- University of Central Florida

- University of Illinois at UrbanaChampaign

- University of Michigan

- University of Texas Austin

- University of Virginia

- University of Washington

- Utah State

- Virginia Tech

- Washington State University

- Other: 


\section{Executive Board Section}

(This section was presented if the respondent answered "Yes" to being in a leadership position)

Are you or have you ever been an officer of your campus ASEE chapter?

- Yes

- No

Where did you get funding? (open response question)

Was funding ever a problem?

- Yes

- No

How did you use your funding? Check all that apply:

$\square$ Food

$\square$ Venue

Speakers

- Chapter paraphernalia

$\square \quad$ Our chapter had no funding

$\square \quad$ Other

Did you have people RSVP for meetings?

$\square$ Yes

口 No

$\square \quad$ Sometimes

How many graduate student members do you currently have?

(open response question)
How many undergraduate student members do you currently have?

(open response question)

How many other (post-doc, faculty, etc.) members do you currently have?

$$
\text { (open response question) }
$$

What percentage of people who RSVP typically participate in the event?

- $0-10 \%$

- $10-20 \%$

- $20-30 \%$

- $30-40 \%$

- $40-50 \%$

- $50-60 \%$

- $60-70 \%$

- $70-80 \%$

- $80-90 \%$

- $90-100 \%$

How have you advertised meetings? Check all that apply:

$\square \quad$ E-mail

$\square$ Facebook

$\square$ Flyers

$\square \quad$ Word of mouth

$\square \quad$ Other social media

$\square$ Other 


\section{Faculty, Staff, and Post-Doc Section}

(This section was presented if the respondent selected "Faculty", "Staff", or "Post-Doc" as their primary classification)

What is your current involvement with the Student Chapter? Check all that apply:

$\square$ Presenter

$\square$ Advisor

$\square$ Other:

Were you involved with a Student Chapter as a student?

- Yes

- No
Would you be more involved if the Chapter was not targeted at students?

- Yes

- No

- Maybe

Which Student Chapter were you involved in?

(open response question) 